\title{
Serial quantification of myocardial infarction tissue heterogeneity during infarct healing by cardiac MRI provides strong characterization of left ventricular remodeling (the NHLBI PROSPECT- CMR Study)
}

\author{
Bobby Heydari ${ }^{*}$, Shuaib M Abdullah', Otavio Coelho-Filho' ${ }^{1}$, François-Pierre Mongeon', Harris Alanna', \\ Yiu Cho Chung ${ }^{2}$, Rob J van der Geest ${ }^{3}$, Michael Jerosch-Herold', Elliott Antman', Raymond Y Kwong ${ }^{1}$
}

From 2011 SCMR/Euro CMR Joint Scientific Sessions

Nice, France. 3-6 February 2011

\section{Objective}

The relationship of infarction heterogeneity with indices of ventricular remodeling quantified during the convalescent phase of acute infarct healing is unknown. We hypothesize that a dynamic increase of the proportion of infarct core relative to peri-infarct zone (PIZ) following acute myocardial infarction (MI) may be associated with adverse remodeling.

\section{Background}

Late gadolinium enhancement (LGE) with infarct tissue heterogeneity characterized by cardiac magnetic resonance imaging (CMR) has been shown to be associated with arrhythmogenic substrates and increased mortality. Preliminary data suggests that areas of heterogeneous signal intensity (SI) within an infarct may represent an admixture of myocardial fibrosis, ischemic cellular apoptosis and viable myocytes potentially capable of functional recovery.

\section{Methods}

We prospectively studied 63 patients with acute MI. Patients underwent CMR 2-4 weeks post MI with follow-up at 6-months. Mean age was $59 \pm 12$ years, and $70 \%$ were male. Successful revascularization was achieved in $>90 \%$ of patients.

'Brigham and Women's Hospital, Boston, MA, USA

Full list of author information is available at the end of the article
Total LGE was divided into infarct core and PIZ by previously described full width half-maximum method. Infarct core and PIZ were defined as regions with maximal SI $\geq 50^{\text {th }}$ and $<50^{\text {th }}$ percentile but $>$ peak SI of remote myocardium, respectively.

\section{Results}

Baseline and 6-month CMR characteristics are shown in Table 1.

Dynamic change of the infarct core to PIZ ratio demonstrated strong correlation with changes in LVESV and LVEF. A dynamic increase of the infarct core to PIZ ratio, even in the setting of total infarct size regression, was significantly associated with increase of LVESV and reduction of LVEF. Percent change of infarct core strongly correlated to percent change of PIZ $(\mathrm{r}=0.66, \mathrm{p}<0.0001)$.

Figure 1 shows the receiver-operating-characteristic (ROC) curve describing the diagnostic performance of percent change of infarct core to PIZ ratio for

Table 1 Baseline and 6 month CMR Characteristics $(n=63)$

\begin{tabular}{lllll}
\hline & Baseline & $\mathbf{6}$ month & \% change & p value \\
\hline Total Infarct $(\mathrm{g})$ & $17 \pm 14$ & $13 \pm 12$ & $28 \pm 22$ & $<0.0001$ \\
Infarct core $(\mathrm{g})$ & $5.5 \pm 5.6$ & $4.0 \pm 4.0$ & $26 \pm 32$ & $<0.0001$ \\
PIZ $(\mathrm{g})$ & $11.5 \pm 9$ & $9 \pm 8$ & $27 \pm 23$ & $<0.0001$ \\
LVEDV $(\mathrm{mL})$ & $178 \pm 50$ & $168 \pm 47$ & $2 \pm 16$ & 0.16 \\
LVESV $(\mathrm{mL})$ & $83 \pm 38$ & $73 \pm 31$ & $8 \pm 21$ & 0.005 \\
LVEF $(\%)$ & $55 \pm 10$ & $58 \pm 8$ & $7 \pm 12$ & $<0.0001$ \\
\hline
\end{tabular}


Table 2 Spearman Correlation of Infarct Characteristics

\begin{tabular}{llll}
\hline & $\begin{array}{l}\text { LVEF }(\% \\
\text { change })\end{array}$ & $\begin{array}{l}\text { LVESV (\% } \\
\text { change) }\end{array}$ & $\begin{array}{l}\text { LVEDV }(\% \\
\text { change) }\end{array}$ \\
\hline $\begin{array}{l}\text { Infarct core }(\% \\
\text { change) }\end{array}$ & $0.28(p=0.04)$ & $0.33(p=0.01)$ & $0.12(p=N S)$ \\
PIZ (\% change) & $0.29(p=0.03)$ & $-0.38(p=0.004)$ & $-0.30(p=0.03)$ \\
\hline
\end{tabular}

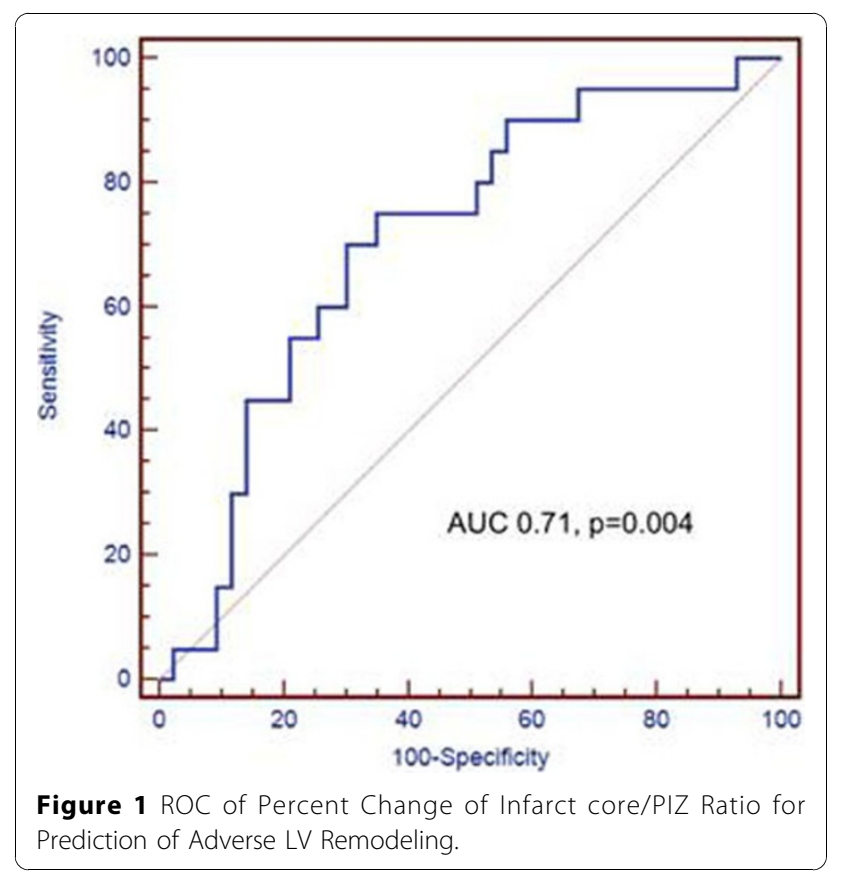

prediction of adverse LV remodeling, with area under the curve (AUC) of 0.71, $\mathrm{p}=0.004$.

\section{Conclusions}

Our results demonstrate that while total LGE regresses, an increase of the infarct core to PIZ ratio during the first 6 months of infarct healing was associated with adverse LV remodeling. These findings provide supportive evidence that heterogeneous infarct tissue characterized by CMR in the acute infarct setting may represent an admixture of necrotic and viable myocardium. A proportional increase of infarct core relative to PIZ following MI may represent further infarct expansion, apoptosis of viable myocytes, and reduction of the extent of recoverable myocardium.

\section{Author details}

'Brigham and Women's Hospital, Boston, MA, USA. ${ }^{2}$ Siemens Medical Systems, Chicago, IL, USA. ${ }^{3}$ Leiden University Medical Center, Leiden, Netherlands.

Published: 2 February 2011
doi:10.1186/1532-429X-13-S1-065

Cite this article as: Heydari et al:: Serial quantification of myocardial infarction tissue heterogeneity during infarct healing by cardiac MRI provides strong characterization of left ventricular remodeling (the NHLBI PROSPECT-CMR Study). Journal of Cardiovascular Magnetic Resonance 2011 13(Suppl 1):O65.
Submit your next manuscript to BioMed Central and take full advantage of:

- Convenient online submission

- Thorough peer review

- No space constraints or color figure charges

- Immediate publication on acceptance

- Inclusion in PubMed, CAS, Scopus and Google Scholar

- Research which is freely available for redistribution

Submit your manuscript at www.biomedcentral.com/submit
C Biomed Central 